\title{
Serum paraoxanase-1 activity in patients with acute otitis media
}

\author{
Akut otitis media hastalarında serum paraoksonaz-1 aktivitesi \\ Sema Koç ${ }^{1}$, Fazilet Duygu' ${ }^{2}$, Ahmet Eyibilen ${ }^{1}$, Nurten Aksoy ${ }^{3}$, Abdullah Taskin ${ }^{3}$, Hasan Bilinc ${ }^{3}$ \\ ${ }^{1}$ Department of Otorhinolaryngology, School of Medicine, Gaziosmanpaşa University, Tokat, Turkey \\ ${ }^{2}$ Department of Infectious Disease and Clinical Microbiology, Tokat State Hospital, Tokat, Turkey \\ ${ }^{3}$ Department of Biochemistry, School of Medicine, Harran University, Şanlıurfa, Turkey
}

\section{ABSTRACT}

Objectives: Paraoxonase is a high-density lipoprotein (HDL)-associated antioxidant enzyme. We aimed to compare the activity of serum paraoxanase-1 (PON 1) in healthy controls and patients with acute otitis media (AOM).

Subjects and methods: We performed a prospective controlled trial in patients with AOM. A total of 60 subjects, 30 patients with AOM (17 male; age, $15 \pm 9$ years) and 30 age- and sex-matched controls (16 male; age, 16 \pm 5 years) were enrolled in this study. PON 1 activity was measured using Mackness' methods.

Results: PON 1 activity was significantly lower in the AOM group compared to control group (155 $\pm 95 \mathrm{U} / \mathrm{L}$ vs. $210 \pm 96 \mathrm{U} / \mathrm{L}, \mathrm{P}=0.04)$.

Conclusions: The present study demostrates that serum PON 1 activity is low in AOM, similar to other conditions with increased oxidative stress. We speculate that PON 1 enzyme is consumed at a greater rate during AOM in order to prevent increased oxidative damage. J Clin Exp Invest 2011; 2 (4): 412-415

Key words: Acute otitis media, paraoxanase-1 activity, oxidative strees

\section{INTRODUCTION}

Acute otitis media (AOM) is one of the most common illnesses of the pediatric age group and is the most important cause of morbidity in children. Several studies have reported that $60-70 \%$ of children experience at least one occurrence in the first four years of life. ${ }^{1}$

The pathophysiology of AOM is still unclear. Some studies show that free oxygen radicals (FRs) increase in the middle ear during middle ear infection and play an important role in the creation of mucosal damage. The free radicals can be a result of cellular metabolism or due to environmental factors. ${ }^{2}$ Oxida-

\section{ÖZET}

Amaç: Paraoksonaz (PON) yüksek dansiteli lipoprotein (HDL) ile ilişkili antioksidan bir enzimdir. Bu çalışmada akut otitis media (AOM) hastaları ile sağlıklı kontrol grubu arasında PON 1 aktivitesini karşılaştırmak amaçlanmaktadır.

Gereç ve yöntem: AOM hastalarında prospektif, kontrollü bir çalışma yaptık. Çalışmaya 30 AOM hastası (17 erkek; yaş, $15 \pm 9$ yıl) ve 30 kontrol grubu (16 erkek; yaş, $16 \pm$ 5) olmak üzere 60 birey dahil edildi. Hasta ve kontrol grubunda Mackness'in metodu ile PON 1 aktivitesi ölçüldü.

Bulgular: Akut otitis media hasta grubunda, kontrol grubuna göre PON 1 aktivitesi düşük düzeyde idi (155 \pm 95 $U / L$ ve $210 \pm 96 \mathrm{U} / \mathrm{L}, \mathrm{P}=0.04$ ).

Sonuç: Akut otitis media'da oksidatif stres oluşmaktadır. Oluşan oksidatif hasarı önlemek amacıyla PON 1 enzimi daha fazla tüketilmektedir. Bu nedenle AOM hastalarında bu enzim aktivitesi düşük düzeyde elde edilmektedir.

Anahtar kelimeler: Akut otitis media, paraoksanaz 1 aktivitesi, oksidatif stres

tive balance is the relationship between the generation of free radicals and the speed of their removal. As long as oxidative balance is maintained, the organism is not affected by the free radicals. If the balance is disrupted in favor of free radicals, oxidative stress results. ${ }^{3}$ It has been shown that oxidative stress due to increased free radicals, has a role in the pathogenesis of many illnesses including cataract, atherosclerosis, myocardial infarction, arthritis, nasal polyposis, presbycusis and head and neck tumors. ${ }^{3-10}$ The defense system protecting against free radical damage involves vitamin $\mathrm{E}$, vitamin $\mathrm{C}$, beta-carotene, glutathione, uric acid, bilirubin and 
various enzymes (glutathione peroxidase, catalase, superoxide dismutase [SOD]). and ceruloplasmin. ${ }^{11}$

The paraoxonase (PON) enzyme has three isoforms, PON 1, PON 2 and PON 3. Paraoxonase-1 (PON 1) is a protein of 354 amino acids. It is synthesized in the liver and almost exclusively located on high-density lipoprotein (HDL). In various trials, it has been shown that paraoxonase prevents oxidative stress by inhibiting the oxidation of cell membrane lipids that is induced by FRs which develop in acute and chronic inflammation. ${ }^{12}$ In this study, we aimed to investigate PON 1 activity in patients with AOM compared to healthy subjects.

\section{Materials and methods}

\section{Study population}

A total of 60 subjects, including 30 patients with $\mathrm{AOM}$ and 30 healthy controls, were enrolled in this study. All AOM patients were in the exudative stage. The physical examination and otoscopic evaluation of the patients were made by an otolaryngologist in 48 hours. Acute otitis media is defined as 1) acute onset (within $48 \mathrm{~h}$ ); 2) signs of inflammation in the tympanic membrane and the presence of middle ear effusion (tympanic membrane redness, bulge, absence of mobility due to the presence of middle ear effusion); 3) acute symptoms of infection (otalgia, fever, irritability, deficiency of hearing). All patients demonstrated these symptoms upon physical examination. Penicillin group antibiotic therapy was started for all patients. Exclusion criteria were acute respiratory infection in the last three months, craniofacial anomaly, anemia, nasal polyps, allergy, chronic tonsillitis and/or adenoid vegetation and complicated AOM. The control group was comprised of completely healthy persons for whom no pathology was diagnosed. The control group underwent otoscopic, and otomicroscobic evaluation and tympanometry. The Ethical Committee of Harran University, Medical Faculty (Sanliurfa, Turkey) approved the study.

\section{Blood sample collection}

After overnight fast, blood samples were collected from patients during the acute phase of the disease or from healthy volunteers. Samples were immediately separated from the cells by centrifugation at $3000 \times \mathrm{g}$ for $10 \mathrm{~min}$, then stored at $-80^{\circ} \mathrm{C}$ until analysis of PON 1 activity.

\section{Measurement of Paraoxanase-1 activity}

The PON activity measurements were performed in the absence (basal activity) and presence of $\mathrm{NaCl}$ (salt-stimulated activity). Briefly, the rate of paraoxon hydrolysis was measured by the increased absorbance at $412 \mathrm{~nm}$ at $25^{\circ} \mathrm{C}$. The amount of generated p-nitrophenol was calculated from the molar absorptivity coefficient at $\mathrm{pH} 8$, which was $17.100 \mathrm{M}-1$ $\mathrm{cm}-1$. The PON activity is expressed as $\mathrm{U} / \mathrm{L}$ serum. Phenylacetate was used as a substrate to measure the arylesterase activity. The reaction was started by the addition of the serum; the increase in absorbance was read at $270 \mathrm{~nm}$. Blanks were included to correct the spontaneous hydrolysis of phenylacetate. Enzymatic activity was calculated from the molar absorptivity coefficient of the produced phenol, $1310 \mathrm{M}-1 \mathrm{~cm}-1$. One unit of arylesterase activity was defined as $1 \mu \mathrm{mol}$ phenol generated/min under the above conditions and expressed as U/L serum. ${ }^{13}$

\section{Statistical analysis}

Continuous variables are expressed as mean $\square$ standard deviation (SD) and gender is written as a percentage. Continuous variables were compared using Student's t test. The Chi-square test was used for gender. SPSS software 15.0 for Windows (Chicago, IL, USA) was used for all statistical analysis. Calculated P-values were considered statistically significant when they were $<0.05$.

\section{RESULTS}

After the treatment period, patients returned for a follow-up visit fifteen days later; all patients had recovered from the illness. No complications of AOM were seen in our patients. There were no differences between patients with AOM and controls in gender (17 male vs. 16 male, $P>0.05)$ and age $(15 \pm 9$ years vs. $16 \pm 5$ years, $P>0.05$ ). The PON 1 activity was significantly lower in the AOM group compared to control group (155 $\pm 95 \mathrm{U} / \mathrm{L}$ vs. $210 \pm 96 \mathrm{U} / \mathrm{L}$, respectively, $\mathrm{P}=0.04$ ) (Table 1 ).

Table 1. Age, gender and paraoxonase-1 activity in acute otitis media and control groups

\begin{tabular}{llll}
\hline & AOM group & Control group $P$ \\
& $(\mathrm{n}=30)$ & $(\mathrm{n}=30)$ & \\
\hline Age, years* & $15 \pm 9$ & $16 \pm 5$ & $>0.05$ \\
Male, $\mathrm{n}(\%)$ & $17(57)$ & $16(53)$ & $>0.05$ \\
PON 1 activity, $\mathrm{U} / \mathrm{L}^{*}$ & $155 \pm 95$ & $210 \pm 96$ & 0.04 \\
\hline
\end{tabular}

AOM, acute otitis media; PON, paraoxanase, *values are presented as mean \pm standard deviation. 


\section{DISCUSSION}

In order to evaluate the impact of AOM on oxidative status, we measured PON 1 activity. To the best of our knowledge, there is the first study examining PON 1 activity in patients with AOM.

Free oxygen radicals occur under physiological conditions during aerobic metabolism in reactive oxygen fields. If either the production of oxygen radicals increases or there are defects in the cellular antioxidant defense system, malfunctions in the cell can result. Free radicals can affect many cell components including cell membrane damage through effects on lipids, inactivation of enzymes due to effects on proteins, polysaccharide depolymerization through effects on carbohydrates. Lipid peroxidation due to FRs is one of the most important causes of cell damage. ${ }^{14}$

It is known that oxygen radicals have a role in the pathogenesis of inflammation. Several studies reported that FRs have role in pathogenesis of AOM; FRs have been found in the middle ear of patients with AOM. Streptococcus pneumonia, the most common pathogen in AOM, produces hydrogen peroxide, which is the most important FR mediator. As the result of lipid peroxidation, the middle ear mucosa is damaged, delaying recovery and facilitating reinfection, potentially leading to hearing deficiency.14 FR-mediated damage in middle ear mucosa has been shown biochemically and histologically in animal experiments. In a guinea pig model, Takoudes et al. ${ }^{15}$ inject Streptococcus pneumonia into one ear of guinea pig models and saline solution into the other ear; in the group in which streptococcus pneumonia is injected, on the fifth day of postoperative inflammatory cell infiltration, submucosal edema and hyperama were found. Also it was found that in the ear that was injected with streptococcus pneumonia, the lipid peroxide (LPO) level was clearly higher than that of the ear injected with saline solution. As a result, it was suggested that FRs emerging from streptococcus pneumonia and neutrophils during infection invade the mucosal cell membrane, and the mucosa thins, becomes dysfunctional, and can cause liquid accumulation and reinfection in the middle ear.

Paraoxonase 1 is an esterase that hydrolyses aromatic carboxylic acid esters and that is related to HDL strictly. During low-density lipoprotein (LDL) cholesterol's oxidation, and thereby during the accumulation of lipid peroxides, HDL cholesterol decreases the lipid peroxides with these enzymatic mechanism. ${ }^{12}$ Several studies have shown that oxidative stress increases and serum PON 1 activity decreases in chronic illnesses such as coronary artery disease, connetive tissue disease, stroke, pulmonary tuberculosis, anemia, Behçet disease and lung cancer 16-20 It is known that PON 1 enzyme has an important role in inflammatory diseases. Işık et al. ${ }^{18}$ showed that oxidative stress increases and PON 1 activity decreases in Behçet disease, a chronic inflammatory disease. They reported that the free oxygen radicals, which emerge result in increasing oxidative stress, might cause the oral and genital ulcers, ocular inflammation, skin and joint symptoms that are characteristic of this disease.

The results of this study were similar to those of the studies given above. The present study demonstrated that serum PON 1 activity was lower in the AOM group compared to the control group. It was speculated that PON 1 enzyme shows antioxidant effects for preventing oxidative damage and when consumed more than normal, prevented an increase in oxidative stress. But, further studies with greater sample size are needed to confirm this hypothesis.

\section{REFERENCES}

1. Pukander J, Sipila M, Kataja M, Karma P. Estimating the risk of acute otitis media among urban children. Ann Otol Rhinol Laryngol 1990;149(3):18-20.

2. Serafini M, Del Rio D. Understanding the association between dietary antioxidants, redox status, and disease: is the total antioxidant capacity the right tool? Redox Report 2004;9(3):145-52.

3. Seidman MD, Ahmad N, Joshi D, Seidman J, Thawani S, Quirk WS. Age-related hearing loss and its association with reactive oxygen species and mitochondrial DNA damage. Acta Otolaryngol Suppl 2004;(552):1624.

4. Doğru H, Delibaş N, Döner F, Tuz M, Uygur K. Free radical damage in nasal polyp tissue. Otolaryngol Head Neck Surg 2001;124(5):570-2.

5. Parks RR, Huang CC, Haddad J Jr. Evidence of oxygen radical injury in experimental otitis media. Laryngoscope 1994;104(11):1389-92.

6. Rasheed MH, Beevi SS, Geetha A. Enhanced lipid peroxidation and nitric oxide products with deranged antioxidant status in patients with head and neck squamous cell carcinoma. Oral Oncol 2007;43(4):333-8.

7. Tissié G, Guillermet V, Latour E, Coquelet C, Bonne C. Oxidative stress and lens opacity: an overall approach to screening anticataractous drugs. Ophthalmic Res 1988;20(1):27-30.

8. Diaz MN, Frei B, Vita JA, Keaney JF. Antioxidants and atherosclerotic heart disease. $\mathrm{N}$ Engl J Med 1997;337(6):408-16.

9. Wickens D, Wilkins MH, Lunec J, Ball G, Dormandy TL. Free radical oxidation (peroxidation) products in se- 
rum and synovial fluid in rheumatoid arthritis. J Rheumatol 1981;8(2):233-45.

10. Machlin LJ, Bendich A. Free radical tissue damage: protective role of antioxidant nutrients. FASEB $\mathrm{J}$ 1987;1(6):441-5.

12. Lipincott W. Paraoxonase a cadioprotective enzyme: continuing issuess. Curr Opin Lipidol 2004;15(3):261-7.

13. Mackness MI, Arrol S, Durrington PN. Paraoxonase prevents accumulation of lipoperoxides in low-density lipoprotein. FEBS Lett 1991;286(1-2):152-4.

14. Haliwell B. Reactive oxygen species in living system: Source biochemistry, and role in human disease. Am J Med 1991(3);91:149-235.

15. Takoudes TG, Haddad J Jr. Lipid peroxides in middle ear fluid after acute otitis media in guinea pigs. Otol Rhinol Laryngol 1999;108(6):564-8.
16. Bodolay E, Seres I, Szodoray P, et al. Evaluation of paraoxonase activity in patients with mixed connective tissue disease. J Rheumatol 2008;35(2):237-43.

17. Selek S, Cosar N, Kocyigit A, et al. PON1 activity and total oxidant status in patients with active pulmonary tuberculosis. Clin Biochem 2008;41(3):140-4.

18. Isik A, Koca SS, Ustundag B, Selek S. Decreased total antioxidant response and increased oxidative stress in Behcet's disease. Tohoku J Exp Med 2007;212(2):133-41.

19. Aslan M, Kosecik M, Horoz M, Selek S, Celik H, Erel O. Assessment of paraoxonase and arylesterase activities in patients with iron deficiency anemia. Atherosclerosis 2007; 191(2): 397-402.

20. Emin T, Elkiran N. Serum paraoxonase and arylesterase activities in patients with lung cancer in a Turkish population. BMC Cancer 2007;7:48-52. 